\title{
Can wood density be efficiently selected at early stage in maritime pine (Pinus pinaster Ait.)?
}

\author{
Laurent BoufFIER ${ }^{1}$, Céline CHARlot $^{2}$, Annie RAFFIN $^{1 *}$, Philippe RozENBERG $^{3}$, Antoine KreMER $^{1}$ \\ ${ }^{1}$ INRA, UMR1202 Biodiversity Genes \& Communities, 33612 Cestas, France \\ ${ }^{2}$ INRA, Experimental Unit, 33612 Cestas, France \\ ${ }^{3}$ INRA Orléans, Unité d'Amélioration, Génétique et Physiologie Forestières, 45166 Ardon, France
}

(Received 26 February 2007; accepted 10 July 2007)

\begin{abstract}
Growth and stem straightness are the two main selection criteria in the French maritime pine breeding programme. In this contribution, our objective was to study the possibility of selecting for wood density assessed at an early stage. We measured X-ray wood density, in three progeny tests, on more than 1900 breast high increment cores. High relative expected genetic gain (from 3 to $9 \%$ ) was found for wood density at mature stage. Juvenile and adult wood density estimations were well-correlated; the relative efficiency of early selection reached about $80 \%$ at 12 years old. As it would not be realistic to use the X-ray densitometer at an operational scale in a breeding programme, we tested the efficiency of using the Resistograph, an indirect method to assess wood density on live trees. High correlation between the Resistograph and density data $\left(R^{2}=0.93\right.$ on familial data) was found, suggesting that wood density through Resistograph assessment could be soon integrated as a new selection criterion in our breeding programme.
\end{abstract}

Pinus pinaster Ait. / wood density / genetic gain / Resistograph / juvenile-adult correlation

Résumé - Peut-on efficacement sélectionner la densité du bois chez le pin maritime (Pinus pinaster Ait.) au stade juvénile ? La croissance et la rectitude du tronc sont les deux principaux critères de sélection dans le programme d'amélioration génétique du pin maritime en France. Cette étude a pour objectif d'évaluer la possibilité de sélectionner la densité du bois au stade juvénile. Plus de 1900 arbres, provenant de trois tests, ont été analysés par microdensitométrie. Des gains génétiques relatifs élevés ont été mis en évidence pour la densité du bois au stade adulte (3 à $9 \%$ ). Les estimations de la densité réalisées aux stades adulte et juvénile étant bien corrélées, l'efficacité relative de la sélection atteint environ $80 \%$ à 1 'âge de 12 ans. Les mesures de densité par rayons X ne sont pas envisageables à grande échelle dans le cadre d'un programme d'amélioration, ainsi nous avons évalué l'efficacité de l'utilisation du Résistographe, une méthode indirecte pour estimer la densité du bois sur arbres debout. Des corrélations élevées ont été mises en évidence entre les données obtenues avec le Résistographe et celles obtenues par microdensitométrie $\left(R^{2}=0.93\right.$ avec les données familiales). Il semble donc possible d'intégrer la densité du bois, estimée avec le Résistographe, comme nouveau critère de sélection dans notre programme d'amélioration.

Pinus pinaster Ait. / densité du bois / gain génétique / Résistographe / corrélation juvénile-adulte

\section{INTRODUCTION}

Maritime pine (Pinus pinaster Ait.) is the most important conifer species in France. Its national distribution extends over 1.4 million ha. The overall harvest of wood amounted to 7.5 million $\mathrm{m}^{3}$ in 2004 of which $31 \%$ was used for pulp industries (paper and plywood), 64\% for sawn timber and 5\% for peeled veneer (data 2004, French Ministry of Agriculture $\mathrm{EAB})$.

In France, maritime pine is mainly localized in Aquitaine where a one million hectare cultivated forest is established. A recurrent selection programme has been developed since the 1960s allowing a 30\% genetic gain expectation both in volume and stem straightness. Today, $70 \%$ of the annual reforestation surfaces are planted with improved seedlings, from second generation seed orchards [12].

Although improving wood quality through wood density is not yet a demand from the timber industry - average wood density for maritime pine is higher than $450 \mathrm{~kg} \cdot \mathrm{m}^{-3}[3,24]-$ breeders have to anticipate future needs; there is a long delay between the introduction of a new selection criterion into the breeding programme and the delivery of improved varieties for the desired criterion. Wood density is likely to be integrated in the selection for the next breeding generation for two main reasons. First, recent results showed that wood density has decreased in successive maritime pine varieties. This decrease can be attributed both to the strong selection on growth and to a higher juvenile wood proportion in the new fast growing varieties. Bouffier et al. [4] estimated that the wood density decrease can reach up to $6 \%$ in the commercial varieties compared to unimproved material. Thus in order to maintain the current wood density level, breeders have to integrate this new criterion in the breeding programme. Second, a higher wood density could allow new uses of maritime pine timber and provide new opportunities for commercialization. Today polyvalent varieties improved for growth and straightness are

*Corresponding author: raffin@pierroton.inra.fr 
Table I. Description of progeny tests and sampling procedure.

\begin{tabular}{|c|c|c|c|c|}
\hline & & Rousset & Hermitage & Pissos \\
\hline Plantation year & & 1974 & 1975 & 1992 \\
\hline Age at sampling time & & 30 & 29 & 12 \\
\hline Complete blocks & & 5 & 4 & 5 \\
\hline Trees per plot & & 3 to 19 & 3,6 or 9 & 10 \\
\hline Seedlings & & Bare-roots & Bare-roots & Containers \\
\hline Fertilisation & & 120 units per ha & - & 60 units per ha \\
\hline \multirow[t]{3}{*}{ Sampling procedure } & Families & 44 & 51 & 51 \\
\hline & Trees per family & 11 to 17 & 10 to 12 & 14 to 15 \\
\hline & Increment cores & 625 & 532 & 764 \\
\hline
\end{tabular}

available. In the future, varieties adapted to specific end uses, such as high wood density varieties, could be developed.

In this study, we assessed wood density using indirect X-ray microdensity analyses, a common and reliable method [21,24, 28]. But the X-ray density assessment, both time-consuming and relatively expensive, is not usable at an operational scale in a breeding programme. As a faster and cheaper method, the Pilodyn tool has been proposed to assess wood density in progeny tests $[14,19,35]$. The Pilodyn penetrometer is an indirect tool for measuring wood density. It is a hand-held instrument which propels a spring-loaded needle into the wood. Depth of needle penetration is read directly from the instrument, and is assumed to be well correlated with wood density. The Pilodyn penetrometer is generally used at breast height, with or without removal of a bark patch. Significant correlations between wood density and Pilodyn depth of needle penetration have been reported for different species. Wang et al. [32] found a correlation of -0.52 in 10-year-old lodgepole pine. Genetic correlations between -0.80 and -0.95 have also been reported in 20-year-old loblolly pine [29], in 12year-old Douglas-fir [19], in 15-year-old interior spruce [35] and in 7-year-old Eucalyptus nitens [14]. Pilodyn heritability ranges from low $(0.22)$ to high values $(0.80)$ [14, 19, 29, 35]. Other studies did not show any significant correlation between wood density and Pilodyn depth of needle penetration such as Livingston et al. [22] in 24-year-old sitka spruce and Villeneuve et al. [31] in 8 to 15 -year-old Black spruce. In Pinus pinaster, Notivol et al. [26] found a high correlation $(-0.73)$ between Pilodyn depth of needle penetration and wood density in 34-year-old trees from different provenances. But Aguiar et al. [1] in Portugal and Pot et al. [28] in France reported respectively no correlation in 12-year-old trees and a very low phenotypic correlation in 14-year-old trees. Moreover, both found no genetic effect for Pilodyn depth of needle penetration. Therefore it appears that Pilodyn is not a reliable tool for wood density assessment in young Pinus pinaster trees. We investigated another tool, the Resistograph, to indirectly estimate wood density in large experimental tests. This method is based on the measure of the drilling resistance of a needle driven with a constant force into a tree. Using this recent promising tool, first encouraging results were reported for Pinus taeda [18], Douglas-fir [6] and Pinus radiata, Pinus caribaea, Eucalyptus globulus, Eucalyptus urophylla [10].

Our objective in this contribution is to evaluate the possibility to select for wood density in maritime pine at a juvenile stage. We shall estimate the genetic gains that can be expected at the adult stage when selecting at a juvenile stage. We will then explore whether the Resistograph is a reliable measurement method to be used in the maritime pine breeding programme.

\section{MATERIALS AND METHODS}

\subsection{Plant material}

Wood density was assessed in three half-sib progeny tests (Rousset, Hermitage and Pissos). Detailed descriptions of the tests are given elsewhere [3] and we report only their main characteristics here (Tab. I). Rousset and Hermitage are respectively 30 and 29 years old, which is considered a mature stage for maritime pine, rotation age varying in the South-West of France between 40 and 50 years old. Pissos is 12 years old which corresponds to the age of genetic selection for growth as well as the first thinning age.

\subsection{Growth and density measurements}

Wood density was assessed on 44 to 51 families per test and a mean of 14 trees per family (Tab. I). In winter 2004, one increment core was collected from each tree at breast height from pith to bark with a $5 \mathrm{~mm}$ diameter increment borer. We actually often sampled several times the same tree to collect a core including the pith or a core passing close to the pith. The samples were cut to a constant thickness of $2 \mathrm{~mm}$ using a double blade saw. Then resins were removed after soaking in pentane for $24 \mathrm{~h}$. Wood density was measured using an indirect-reading X-ray densitometer [27]. The radial density profile was obtained by analysing the scanned images with WinDENDRO software [33]. Ring limits were automatically determined then manually checked and corrected using this software. For each density profile, we estimated ring width (RW) and ring density (RD). 


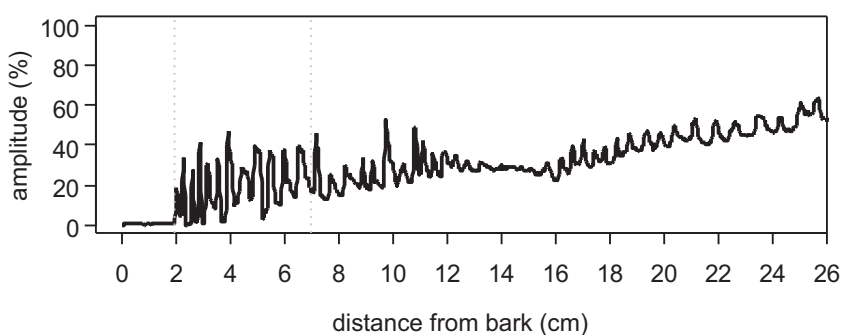

Figure 1. Example of Resistograph profile obtained on an Hermitage tree. Resistograph profiles were integrated on the $5 \mathrm{~cm}$ section delimited by the two grey dotted lines.

Analyses were conducted on cumulative data. The wood density averages for each core age were obtained as the mean values of annual growth rings present at breast height in the sample up to that age weighted by their respective width.

\subsection{Resistograph measurements}

Wood density was also indirectly estimated with the Resistograph F-300S manufactured by IML (Instrumenta Mechanik Labor GmbH, Germany; http://www.iml.de). The Resistograph is based on a drilling resistance measuring method: a drilling needle penetrates into the wood with a constant advance speed and the drilling resistance is recorded each $0.1 \mathrm{~mm}$. This tool was equipped with a powerful battery allowing several hours charge. Resistance profiles stored in the electronic unit were downloaded with the software F-tools provided with the Resistograph.

Two tests were chosen for the Resistograph measures: one at a mature stage (Hermitage) and one at the selection stage (Pissos). In winter 2005, trees were drilled at 5 to $10 \mathrm{~cm}$ above the hole of the increment core. Two adjacent Resistograph measures were performed per tree (data called resisto 1 and resisto 2 ): holes were about $5 \mathrm{~cm}$ spaced. Each Resistograph profile was processed by integrating the amplitude curve of the first five centimetres segment from the bark with the software Interesis from Xyloméca (http://perso.orange.fr/xylomeca). As an example, one profile is presented in Figure 1. Only the five first centimetres were considered for two main reasons. The first one is that, above this limit, profiles display an increasing trend in resistance [10] with less distinct ring boundaries. This unreliable measure above $5 \mathrm{~cm}$ can be explained by the presence of sawdust in the hole and the fact that the needle can bend when it travels trough the wood. The second one is that we consider a measure usable at an operational scale i.e. fast enough (200 trees/day).

Trees exhibiting a large discrepancy between resisto 1 and resisto 2 were removed from the analysis. The threshold of discrepancy was 0.50 , i.e. trees for which the following index was larger than 0.50 were discarded:

$$
\frac{\mid \text { resisto } 1-\text { resisto } 2 \mid}{\text { resisto } 1} \geq 0.50 \text {. }
$$

Consequently $3.1 \%$ of the trees sampled at Hermitage (respectively $7.9 \%$ at Pissos) were not considered in this study. Two Resistograph measurements are necessary to eliminate outlier values (probably due to knots, resin pockets or other abnormalities in the wood). We will henceforth call resisto the mean value between resisto 1 and resisto2.

Repeatability of Resistograph measures was estimated as the coefficient of determination of the following analysis of variance:
$Y_{i j}=\mu+T_{i}+\varepsilon_{i j}$ where $Y_{i j}$ is a Resistograph measure, $\mu$ the general mean, $T_{i}$ the tree effect and $\varepsilon_{i j}$ the residuals.

The Resistograph assessments were made one year after the density measures. Hence there is no exact ring correspondence between the Resistograph and the density profiles. As the contribution of the last ring to the $5 \mathrm{~cm}$ long Resistograph segment is very small (mean ring widths in 2004 were $2.2 \mathrm{~mm}$ at Hermitage and $2.8 \mathrm{~mm}$ at Pissos), it does not strongly modify the Resistograph estimation.

\subsection{Statistical analyses}

Growth, wood density and Resistograph data were analysed with the following linear mixed model:

$$
Y_{i j k}=\mu+b_{i}+F_{j}+b \times F_{i j}+\varepsilon_{i j k}
$$

where $Y_{i j k}$ is the phenotypic individual observation, $\mu$ the general mean, $b_{i}$ the block effect, $F_{j}$ the family effect and $\varepsilon_{i j k}$ the residuals, $b$ was considered as a fixed effect, while $F$ and $b \times F$ were treated as random effects.

The different variance components were estimated according to quantitative genetic models. The phenotypic variance was estimated as $\sigma_{P}^{2}=\sigma_{F}^{2}+\sigma_{b \times F}^{2}+\sigma_{\text {error }}^{2}$ where $\sigma_{F}^{2}$ is the family variance, $\sigma_{b \times F}^{2}$ the interaction block $\times$ family variance and $\sigma_{\text {error }}^{2}$ the residual variance. Families were half-sibs, therefore the genetic variance was estimated as $\sigma_{A}^{2}=4 \times \sigma_{F}^{2}$.

The phenotypic correlation $\left(r_{P}\right)$ and genetic correlation $\left(r_{G}\right)$ between a wood density trait, $x$, and a growth trait, $y$, were estimated as follows:

$$
r_{P}=\frac{\operatorname{Cov}_{P}(x, y)}{\sqrt{\sigma_{P x}^{2} \times \sigma_{P y}^{2}}} \text { and } r_{G}=\frac{\operatorname{Cov}_{A}(x, y)}{\sqrt{\sigma_{A x}^{2} \times \sigma_{A y}^{2}}}
$$

where $\operatorname{Cov}_{P}(x, y)$ and $\operatorname{Cov}_{A}(x, y)$ are the phenotypic covariance and additive genetic covariance between traits $x$ and $y$, respectively.

Analyses were conducted with the restricted maximum-likelihood method using the software ASReml [11] and standard errors were calculated following Gilmour et al. [11].

\subsection{Predicted genetic gain and relative efficiency}

Relative genetic gain was estimated by dividing the expected response $(R)$ by the mean of the trait considered and expressed as a percentage. $\mathrm{R}$ was calculated under three different methods of selection [9]: individual, familial and combined selection. Theoretically, familial selection is more efficient than individual selection for low heritability and inversely for high heritability [5]. Based on our data, genetic gains are very similar whatever the selection strategy considered, probably due to moderate heritabilities. Thus, we will only present results for the individual selection.

For individual selection:

$$
R=i \times \sigma_{P} \times h^{2}
$$

with: $i=1.4$ (selection of the $20 \%$ best units);

$\sigma_{P}=$ phenotypic standard deviation;

$h^{2}=$ individual heritability.

Indirect selection is evaluated using relative efficiency $(R E)$ defined by Falconer [9]:

$R E=r_{G_{j-m}} \times \frac{h_{\text {juvenile }}}{h_{\text {mature }}}$ for individual selection

with: $h_{\text {mature }}=$ square root of heritability at mature age; 

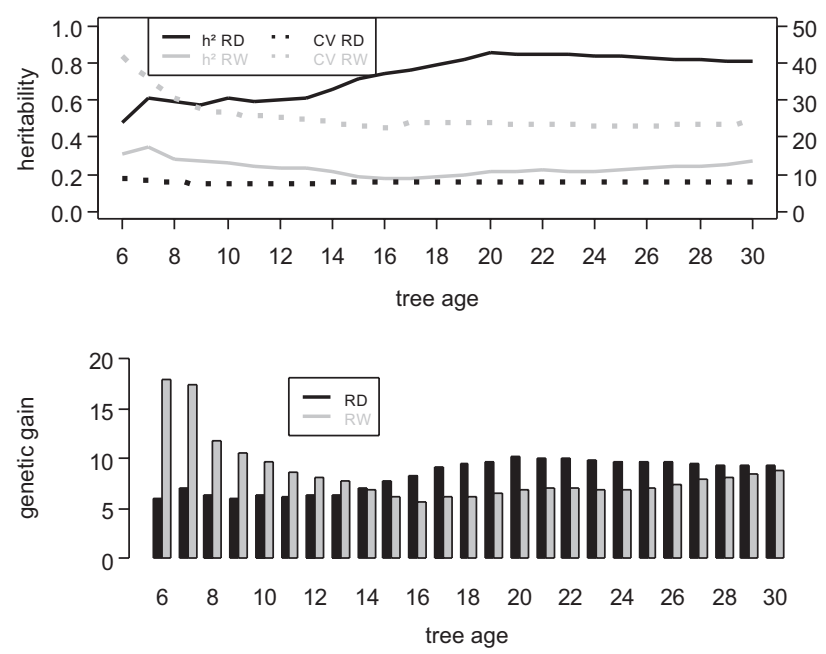

Figure 2. Variation of heritability, phenotypic coefficient of variation and individual genetic gain for ring density and ring width according to cumulative age at Rousset. Genetic gain is calculated as the percentage of the mean for the trait considered. This gain is expressed, for each tree age, for a selection at the same age. RD: ring density; RW: ring width.

$h_{\text {juvenile }}=$ square root of heritability at juvenile age;

$r_{G_{j-m}}=$ genetic correlation between juvenile and mature ages.

Thus $R E$ is the percentage of the expected response if selection is made at juvenile age instead of mature age. $R E$ was also used to evaluate the efficiency of Resistograph assessments compared to wood density measurements.

\section{RESULTS}

\subsection{Expected genetic gain and its components for wood density vs. growth}

Genetic gain and its components (heritability and phenotypic coefficient of variation) were estimated for ring density (RD) and ring width (RW) based on the annual cumulative data. We present results only for Rousset in Figure 2, as trends were similar for the two other tests.

Even if the heritability and coefficient of variation are different depending on the test and on tree age - this consideration is discussed in a previous article [3] - we always observed a higher heritability and a lower coefficient of variation for RD compared to RW.

At mature age (30 and 29 years old), relative genetic gain based on individual selection $(i=1.4)$ is $9 \%$ at Rousset for RD and RW, 3\% for RD and 6\% for RW at Hermitage. For the Pissos test, relative genetic gains expected at 12 years old are $6 \%$ for both characters.

Gains at juvenile age are high for RW at Rousset but ageage correlations are low for age under 8 (see below).

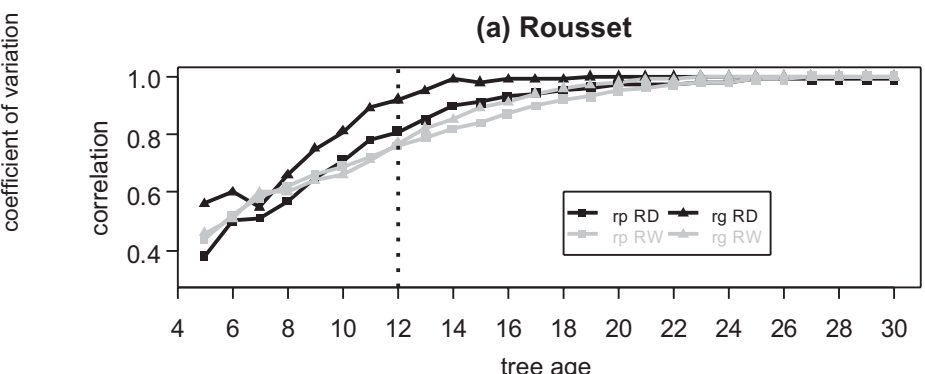

(b) Hermitage

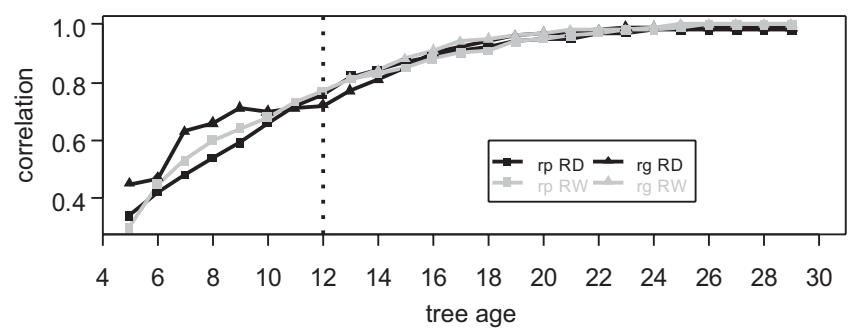

Figure 3. Age - age correlations for ring density and ring width at Rousset (a) and Hermitage (b). Correlations are estimated between age $n$ (cumulative data from pith to ring corresponding to age $n$ ) and mature age (cumulative data from pith to ring corresponding to age 30 and 29 for respectively Rousset and Hermitage). RD: ring density; $\mathrm{RW}$ : ring width; $\mathrm{r}_{P}$ : phenotypic correlation; $r_{G}$ : genotypic correlation; Log-likelihood of the model does not converge for RW up to age 12 at Hermitage.

\subsection{Age-age correlations}

Age-age correlation should be theoretically estimated on different trees to handle uncorrelated residuals. But from the breeding viewpoint, we are also interested in determining correlations on the same tree samples. Breeders actually need to define at which age a character can be measured i.e. well correlated to its adult assessment.

Age-age correlations are presented in Figure 3 for the two older tests (Rousset and Hermitage). For each year, we report $r_{P}$ and $r_{G}$ for RD and RW between the trait value estimated until the year considered and its assessment based on the whole profile (i.e. 30 years for Rousset and 29 years for Hermitage). Both traits show similar trends: the correlation is high even at juvenile age (higher than 0.4 at 6 years old) and increases rapidly. At Rousset, between 8 and 18 years old, correlations are higher for RD than RW whereas the correlations are comparable at Hermitage. At 12 years, genetic correlation for RD is 0.92 at Rousset and 0.72 at Hermitage.

Table II also presents age-age correlations for RD and RW but here juvenile and mature data are independent in the way that we actually compared the wood section before 16 years old with the one after 16 years old. The results are different depending on the character considered: higher values are observed for RD $\left(r_{P}=0.80\right.$ at Rousset and $r_{P}=0.74$ at Hermitage) than for RW $\left(r_{P}=0.47\right.$ at Rousset and $r_{P}=0.49$ at Hermitage). 
Table II. Correlations between ring section before 16 years and ring section after 16 years.

\begin{tabular}{lcccc}
\hline & \multicolumn{3}{c}{ Rousset } & \multicolumn{2}{c}{ Hermitage } \\
\cline { 2 - 5 } \cline { 3 - 5 } & RD & RW & RD & RW \\
\hline$r_{P}(\mathrm{SE})$ & $0.80(0.02)$ & $0.47(0.03)$ & $0.74(0.02)$ & $0.49(0.03)$ \\
$r_{G}(\mathrm{SE})$ & $0.98(0.03)$ & $0.71(0.25)$ & $0.67(0.16)$ & $0.44(0.28)$ \\
\hline
\end{tabular}

RD: ring density; RW: ring width; $r_{P}$ : phenotypic correlation; $r_{G}$ : genotypic correlation; SE: standard error.

Table III. Correlations between Resistograph and wood density data and heritability estimates at the individual level.

\begin{tabular}{lclc}
\hline & & Hermitage & Pissos \\
\hline$r_{P}(\mathrm{SE})$ & resisto1-resisto2 & $0.79(0.02)$ & $0.77(0.01)$ \\
& resisto-RDtot & $0.64(0.03)$ & $0.70(0.02)$ \\
& resisto-RD5cm & $0.64(0.03)$ & $0.69(0.02)$ \\
\hline \multirow{2}{*}{$r_{G}(\mathrm{SE})$} & resisto1-resisto2 & $0.98(0.02)$ & $0.96(0.02)$ \\
& resisto-RDtot & $0.87(0.12)$ & $0.95(0.05)$ \\
& resisto-RD5cm & $0.83(0.12)$ & $0.96(0.05)$ \\
\hline \multirow{2}{*}{ Heritability (SE) } & resisto & $0.32(0.18)$ & $0.43(0.16)$ \\
& RDtot & $0.27(0.16)$ & $0.61(0.17)$ \\
\hline
\end{tabular}

Resisto 1 and resisto2: two Resistograph measures of the same tree; resisto: mean between resisto 1 and resisto2; RDtot: mean ring density from pith to bark; RD5cm: mean ring density of the first $5 \mathrm{~cm}$ from the bark; $r_{P}$ : phenotypic correlation; $r_{G}$ : genotypic correlation; SE: standard error.

\subsection{Relative efficiency for wood density and ring width}

Relative efficiencies of early selection vs. selection at the adult stage were estimated for individual selection at successive ages (data not shown). Relative efficiency is higher for RD than RW, particularly at Hermitage. At 12 years, relative efficiency at Rousset is $79 \%$ for RD (respectively $71 \%$ for RW) and is $83 \%$ at Hermitage for RD (respectively $70 \%$ for RW).

\subsection{Relation between wood density and Resistograph data}

Repeatability between the two Resistograph measures, obtained on the same tree, is high: 0.87 at Hermitage and 0.86 at Pissos, estimated using data on all sampled trees. After excluding the unreliable measures (see Sect. 2), repeatability reaches 0.89 in both tests.

Correlations between Resistograph and wood density data at the individual level are reported in Table III. The Resistograph data are well correlated both with the density based on the first $5 \mathrm{~cm}$ from the bark and with the entire profile $\left(r_{G}\right.$ is higher than 0.80 in both tests). The phenotypic correlation can be well visualised in Figure 4a where individuals from both tests are represented $\left(r^{2}=0.41\right.$ at Hermitage, $r^{2}=0.50$ at Pissos and $r^{2}=0.73$ using both tests). The coefficient of determination $r^{2}$ between resito and RD5 $\mathrm{cm}$ increases if we consider familial data (Fig. 4b): $r^{2}=0.52$ at Hermitage, $r^{2}=0.76$ at Pissos and $r^{2}=0.93$ using both tests. Moreover the "test" has no significant effect ( $p$ value $=0.11$ with an analysis of (a) Individual data

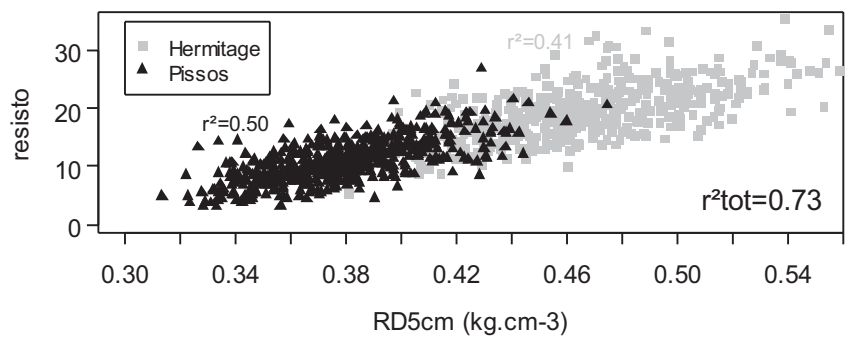

(b) Familial data

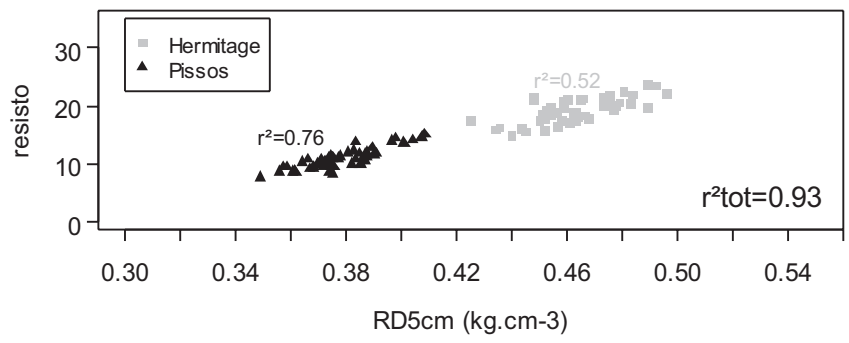

Figure 4. Correlation between wood density and Resistograph measures based on individual (a) and familial data (b). RD5cm: mean wood density on the first $5 \mathrm{~cm}$ from the bark; resisto: mean between the two Resistograph measures on the first $5 \mathrm{~cm}$ from the bark.

covariance) on the correlation between wood density and Resistograph measures.

\section{DISCUSSION}

\subsection{High genetic gains expected for wood density}

Depending on the test, genetic gains expected for RD, considering a selection of the $20 \%$ best individuals, vary from 3 to $9 \%$ of the mean wood density. These gains appear almost constant whatever the age considered. As often observed by other authors [7,36], RD is more heritable but less variable than RW, thus, RD and RW display similar expected gains.

Wood density gains presented here are those obtained when density is the only selection criterion. If wood density is selected for in the maritime pine breeding programme, it is likely to be integrated in a global index together with growth and stem straightness to breed for polyvalent varieties. Although we observed a wood density decrease in the varieties of successive generations improved for growth, density 
appears weakly negatively correlated with growth. For example, for Rousset at 10 years, the genetic correlation was -0.30 $(\mathrm{SE}=0.27)$ between height and $\mathrm{RD}$, and $-0.01(\mathrm{SE}=0.28)$ between RW and RD [4]. Thus it seems feasible to improve growth and stabilize or increase wood density at the same time.

\subsection{Juvenile wood density is a reliable predictor of overall wood density}

As mentioned by Vargas-Hernandez and Adams [30], ageage correlations can be evaluated with different approaches depending on the section of the profile that is used: the whole core, individual growth rings or aggregated growth rings. This makes it difficult to compare results between studies. In this contribution, we chose to compute age-age correlations by taking into account all the rings from the pith up to the ring of the considered age. The values for RD and RW used are therefore those that would have been obtained if increment core samples were taken every year at breast height.

\subsubsection{Favourable age-age correlation}

Age-age correlations are high for RD and RW. At 12 years of age, which is about the current selection age for growth and form, genetic correlation for RD is higher than 0.70 whatever the test considered. These results are in agreement with previous studies. In Pinus pinaster, genetic correlations have been established previously only on young trees; Louzada and Fonseca [24] found genetic correlations between earlier ages and cambial age 13 from 0.94 to 1 . Kumar and Lee [20], Li and $\mathrm{Wu}$ [21] and $\mathrm{Wu}$ et al. [34] worked on rotation-aged radiata pine: genetic correlations superior to 0.8 were reported from cambial age 3 to 15 depending on the test. Similar results have also been found on 25 years old Pinus taeda [16, 23], on Norway spruce [17] and on Douglas-fir [30]. Juvenileadult correlations were studied on Douglas-fir from 50 to 71 years old by McKimmy and Campbell [25] and Gonzales and Richards [13]: they reported correlations from 0.68 to 0.95 depending on the core section considered.

Age-age correlation for RD is higher than for RW at Rousset, particularly between 8 and 18 years, but they are comparable at Hermitage. Better age-age correlation for wood density than growth traits have been reported in several studies [21, 24, 25]. This may be partially explained by the fact that heritability for wood density is higher than for ring width (Fig. 2).

Moreover, phenotypic correlations are of the same magnitude as genetic correlations (Fig. 3), suggesting that the cause of the correlation is mainly genetic and not dependent on the environment. Our data confirm previous studies $[16,21,23,30]$ in this regard. The high correlation between juvenile and mature wood density may suggest that, for this trait, the same clusters of genes act during tree development.

\subsubsection{High relative efficiency}

Our data do not allow estimation of relative efficiency based on the harvest age which is currently at about 45 years for French maritime pine. We estimated relative efficiency based on 30 years (Rousset) and 29 years (Hermitage) data. As wood density does not change much for mature age [37], relative efficiency presented in this study is probably close to that which would have been calculated using an older reference age.

The high relative efficiency for RD found in our study results from a combined effect of high juvenile-mature correlation and a relatively constant heritability through development. High $R E$ for wood density appears as a general result in other species. Vargas-Hernandez and Adams [30] found a relative efficiency of $79 \%$ at 7 years compared with 15 years old on Douglas-fir. In Pinus radiata, similar results were also reported [20,21,34]. If we consider the current selection age (12 years old), relative efficiency for RD is higher than for RW particularly at Hermitage because of a null heritability for RW during the first years.

RD exhibits both high genetic gain and high relative efficiency at selection age. Thus, based on these results, juvenile selection is feasible for wood density in French maritime pine. The efficiency of juvenile selection for this trait should be even higher than for growth selection. Many authors have also concluded that juvenile selection is feasible for wood density in different pine species: Gwaze et al. [16], Atwood et al. [2] and Loo and Tauer [23] on Pinus taeda, Li and Wu [21] and Kumar and Lee [20] on Pinus radiata.

\subsubsection{Feasible selection on a section of rings}

When age-age correlations are estimated between cumulative data, autocorrelations are induced because one character is included in the other. Here, we showed that juvenile-mature correlation remains high for RD even if we consider different ring sections (Tab. II). Whatever the species considered, similar results were found for wood density $[8,15,23,30]$. These results indicate that sampling only a few rings for assessments of wood density is adequate, thus permitting ease future high throughput measurements in breeding programmes. This suggestion was further evaluated by comparing correlation between wood density over the first centimetres from the bark and over the whole core for Hermitage and Pissos. Figure 5 shows that if we consider the first five centimetres from the bark, the phenotypic and genetic correlations are close to 1. Figure 5 also shows the variation of the number of rings present in the $5 \mathrm{~cm}$ section from the bark. A mean of 10 rings are present at Pissos whereas 16 rings occur at Hermitage. This difference comes from age difference between the two tests; Pissos is younger so the ring widths are larger. Whatever the number of rings taken into account, the high correlation suggests that, for operational purpose, assessments of wood density can be limited to the first $5 \mathrm{~cm}$ from the bark. 
(a) Hermitage

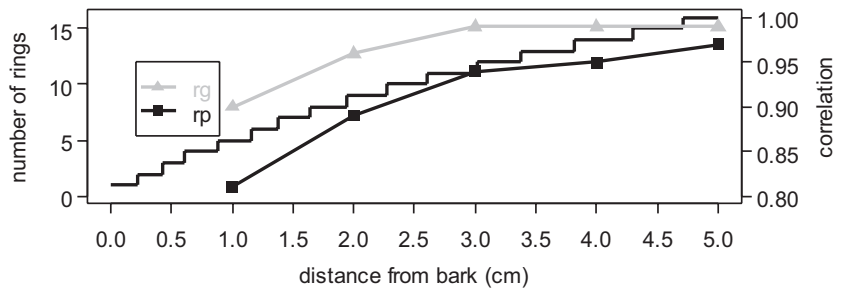

(b) Pissos

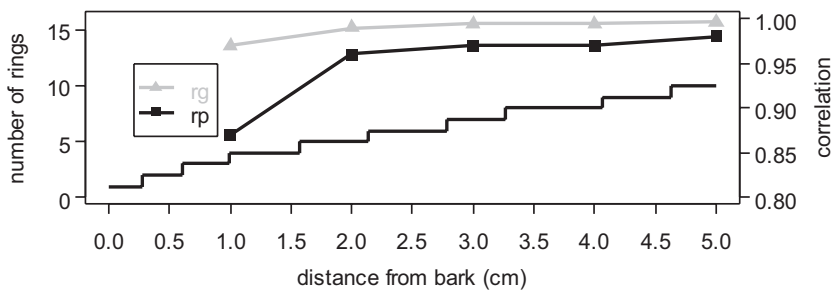

Figure 5. Correlation between wood density estimated from 1 to $5 \mathrm{~cm}$ from the bark and from the whole profile at Hermitage (a) and Pissos (b). Mean number of rings from the bark is also reported. $r_{P}$ : phenotypic correlation; $r_{G}$ : genotypic correlation.

\subsection{Resistograph: a useful tool for operational wood density assessment in breeding programmes}

Our results suggest that wood density could be used as a selection criterion and may be assessed on the last formed rings at a juvenile age. However X-ray wood density assessment is time consuming and too expensive to be used for large scale measurements in a breeding programme. In the introduction, we reported studies showing that Pilodyn penetrometer was not efficient enough to estimate wood density in maritime pine. Consequently we tested another tool allowing indirect wood density estimation, the Resistograph.

Resistograph measures were taken over the first $5 \mathrm{~cm}$ from the bark in a trade-off between accuracy and time efficiency. Even if repeatability of Resistograph measures is high, we decided to consider two measures per tree in order to remove outlier values. Thus each individual Resistograph data is a mean between two measures. Correlations between Resistograph data and wood density estimated over the same core section or over the whole profile are similar because those two last traits are well-correlated. Moreover the high correlation between Resistograph data and density suggests that the Resistograph can be a useful tool for wood density assessments in breeding programmes. Correlations based on individual data are high and are improved when they are computed on mean familial data (Fig. 4). Efficiency of indirect selection for wood density with the Resistograph at the individual level is high, reaching $95 \%$ at Hermitage and $80 \%$ at Pissos (based on estimates in Tab. III). Although Hermitage and Pissos present different wood density ranges, our analysis demonstrated that Resistograph can predict wood density over a wide density scale with the same linear regression. The linear regression was estimated only at two sites and it is recommended to be verified at other sites.
Chantre and Rozenberg [6] found a good correlation between Resistograph and wood density assessments $(r=0.62)$ on 42 Douglas-fir at 23 years. Gantz [10] evaluated the Resistograph in two softwood (Pinus radiata and Pinus caribaea) and two hardwood (Eucalyptus globulus and Eucalyptus urophylla) species at a juvenile stage (i.e. from 4 to 16 years). Resistograph measures were moderately correlated with density data (from 0.30 to 0.78 ) but genetic correlations were close to 1. Isik and Li [18] studied the use of Resistograph for wood density selection on 11-year-old Pinus taeda. The low phenotypic correlation (0.12) at four sites between Resistograph data and wood density contrasts with the high genetic correlation (0.95).

To sum up, phenotypic correlations appear weaker in other species than maritime pine suggesting a larger environmental effect.

Wood quality is often well-predicted by wood density. In this contribution, we show that this trait is moderately variable but highly heritable and it can be selected at juvenile stage. The use of indirect measurements with the Resistograph would allow the rapid integration of wood density into the French maritime pine breeding programme.

Acknowledgements: We wish to thank Bernard Issenhut, Christophe Gauvrit, Laurent Severin, Henri Bignalet from the INRA Pierroton Experimental Unit and Dominique Charon from INRA UMR BIOGECO for their help to collect the increment cores and for Resistograph measurements. Michel Sartore, from INRA UMR EPHYSE, improved Resistograph tool for large scale measures. We thank also Pierre Alazard from AFOCEL for establishing and maintaining the Pissos plantation. All microdensity X-ray photographs were obtained at INRA Orléans by Frédéric Millier. We also appreciated discussions throughout the project with Gérard Nepveu from INRA Nancy. This work was supported by funding from the French Ministry of Agriculture and the Région Aquitaine by way of the GIS "Pin Maritime du Futur".

\section{REFERENCES}

[1] Aguiar A., Almeida M.H., Borralho N., Genetic control of growth, wood density and stem characteristics of Pinus pinaster in Portugal, Silva Lusitana 11 (2003) 131-139.

[2] Atwood R.A., White T.L., Huber D.A., Genetic parameters and gains for growth and wood properties in Florida source loblolly pine in the southeastern United States, Can. J. For. Res. 32 (2002) 10251038.

[3] Bouffier L., Rozenberg P., Raffin A., Kremer A., Wood density variability in successive breeding populations of maritime pine, Can. J. For. Res. (submitted).

[4] Bouffier L., Raffin A., Rozenberg P., Meredieu C., Kremer A., What are the consequences of growth selection on wood density in the French maritime pine breeding programme? Tree Genet. Genomes (submitted).

[5] Burdon R.D., Kumar S., Forwards versus backwards selection: trade-offs between expected genetic gain and risk avoidance, N.Z. J. For. Sci. 34 (2004) 3-21.

[6] Chantre G., Rozenberg P., Can drill resistance profiles (Resistograph) lead to within-profile and within-ring density parameters in Douglas-fir wood? in: Proc. of CTIA - IUFRO International Wood Quality Workshop: Timber Management Toward Wood Quality and End-Product Value, Québec, 18-22 August 1997, pp. 41-47. 
[7] Cornelius J., Heritabilities and additive genetic coefficients of variation in forest trees, Can. J. For. Res. 24 (1994) 372-379.

[8] Cown D.J., Young G.D., Burdon R.D., Variation in wood characteristics of 20-year-old half-sib families of Pinus radiata, N.Z. J. For. Sci. 22 (1992) 63-76.

[9] Falconer D.S., Introduction à la génétique quantitative, Masson, Paris, 1974.

[10] Gantz C.H., Evaluating efficiency of the Resistograph to estimate genetic parameters for wood density in two softwood and two hardwood species, Master of Science, North Carolina State University, 2002, 78 p.

[11] Gilmour A.R., Gogel B.J., Cullis B.R., Welham S.J., Thompson R., ASReml User Guide Release 1.0 (2002), VSN International Ltd, Hemel Hempstead, HP1 1ES, UK, 2002.

[12] GIS collective work, Alazard P., Canteloup D., Cremiere L., Daubet A., Lesgourgues Y., Merzeau D., Pastuszka P., Raffin A., Genetic breeding of the maritime pine in Aquitaine, GIS Work Report, 2002, $80 \mathrm{p}$.

[13] Gonzalez J.S., Richards J., Early selection for wood density in young coastal Douglas-fir trees, Can. J. For. Res. 18 (1988) 1182 1185 .

[14] Greaves B.L., Borralho N.M.G., Raymond C.A., Farrington A., Use of a Pilodyn for the indirect selection of basic density in Eucalyptus nitens, Can. J. For. Res. 26 (1996) 1643-1650.

[15] Gwaze D.P., Bridgwater F.E., Byram T.D., Lowe W.J., Genetic parameter estimates for growth and wood density in Loblolly pine (Pinus taeda L.), For. Genet. 8 (2001) 47-55.

[16] Gwaze D.P., Harding K.J., Purnell R.C., Bridgwater F.E., Optimum selection age for wood density in loblolly pine, Can. J. For. Res. 32 (2002) 1393-1399.

[17] Hylen G., Age trends in genetic parameters of wood density in young Norway spruce, Can. J. For. Res. 29 (1999) 135-143.

[18] Isik F., Li B., Rapid assessment of wood density of live trees using Resistograph for selection in tree improvement programs, Can. J. For. Res. 33 (2003) 2426-2435.

[19] King J.N., Yeh F.C., Heaman J.C., Dancik B.P., Selection of wood density and diameter in controlled crosses of coastal Douglas-fir, Silvae Genet. 37 (1988) 152-157.

[20] Kumar S., Lee J., Age-age correlations and early selection for endof-rotation wood density in radiata pine, For. Genet. 9 (2002) 323330.

[21] Li L., Wu H.X., Efficiency of early selection for rotation-aged growth and wood density traits in Pinus radiata, Can. J. For. Res. 35 (2005) 2019-2029.

[22] Livingston A.K., Cameron A.D., Petty J.A., Lee S.L., Effect of growth rate on wood properties of genetically improved Sitka spruce, Forestry 77 (2004) 325-334.
[23] Loo J.A., Tauer C.G., Juvenile - mature relationships and heritability estimates of several traits in loblolly pine (Pinus taeda), Can. J. For. Res. 14 (1984) 822-825.

[24] Louzada J.L.P.C., Fonseca F.M.A., The heritability of wood density components in Pinus pinaster Ait. and the implications for tree breeding, Ann. For. Sci. 59 (2002) 867-873.

[25] McKimmy M.D., Campbell R.K., Genetic variation in the wood density and ring width trend in coastal Douglas-fir, Silvae Genet. 31 (1982) 43-51.

[26] Notivol E., Gil L.A., Pardos J.A., A method for estimating wood density in standing trees and its variability in Pinus pinaster, Investig. Agrar. Sist. Recur. For. 1 (1992) 41-47.

[27] Polge H., Établissement des courbes de variation de la densité du bois par exploration densitométrique de radiographies d'échantillons prélevés à la tarière sur des arbres vivants, Ann. Sci. For. 23 (1966) 1-206.

[28] Pot D., Chantre G., Rozenberg P., Rodrigues J.C., Jones G.L., Pereira H., Hannrup B., Cahalan C., Plomion C., Genetic control of pulp and timber properties in maritime pine (Pinus pinaster Ait.), Ann. For. Sci. 59 (2002) 563-575.

[29] Sprague J.R., Talbert J.T., Jett J.B., Bryant R.L., Utility of the Pilodyn in selection for mature wood specific gravity in loblolly pine, For. Sci. 29 (1983) 696-701.

[30] Vargas-Hernandez J., Adams W.T., Age-age correlations and early selection for wood density in young coastal Douglas-fir, For. Sci. 38 (1992) 467-478

[31] Villeneuve M., Morgenstern E.K., Sebastian L.P., Estimation of wood density in family tests of jack pine and black spruce using Pilodyn tester, Can. J. For. Res. 17 (1987) 1147-1149.

[32] Wang T., Aitken S.N., Rozenberg P., Carlson M.R., Selection for height growth and Pilodyn pin penetration in lodgepole pine: effects on growth traits, wood properties, and their relationships, Can. J. For. Res. 29 (1999) 434-445.

[33] WinDENDRO User guide (2003) Regent Instruments Inc., Québec, 2003.

[34] Wu H.X., Powell M.B., Yang J.L., Ivkovic M., McRae T.A., Efficiency of early selection for rotation-aged wood quality traits in radiata pine, Ann. For. Sci. 64 (2007) 1-9.

[35] Yanchuk A.D., Kiss G.K., Genetic variation in growth and wood specific gravity and its utility in the improvement of interior spruce in British Columbia, Silvae Genet. 42 (1993) 141-148.

[36] Zobel B.J., Jett J.B., Genetics of wood production, Springer-Verlag, Berlin, 1995.

[37] Zobel B.J., van Buijtenen J.P., Wood variation: its causes and control, Springer-Verlag, Berlin, 1989. 